\section{New idea on South Africa}

SIR-We are a group of South African academics, two of whom are citizens by birth. We feel a great deal of sympathy with those people abroad who are attempting to bring about change in this country through the application of boycotts. Experience has taught us that the most effective actions have involved trade, and nationalistic activities, particularly in the field of sport. There is, however, also a strong argument for academic boycotts, as many of the people with whom we come into daily contact are very much a part of the South African problem. Few of our universities are multiracial, and even those that practise a form of integration are certainly not blameless.

One of the problems with blanket boycotts, however, is that they generate a sense of martyrdom, giving credence to the defensive argument that the rest of the world is concentrating on our problems to avoid confronting their own. More unfortunately, they fail to take cognisance of the efforts of people like Professor Phillip Tobias, who have openly fought racist policies in this country ever since they have been in positions to do so.

We should like to propose an alternative to an all-out academic boycott which, by its positive nature, might help to alleviate the unfortunate situation in this country. When academics from South African institutions submit manuscripts to international journals, or apply for admission to conferences overseas, they should be required to sign a declaration to the following effect: (1) that they do not support an academic or social system that is based on inequality or discrimination, and (2) that they are in favour of science as a united and cooperative activity which is not divided by artificial barriers of race, sex or religion. In this way, they will be forced to show their true colours, so to speak, rather than being able to fall back on the excuse that the rest of the world is fighting apartheid with a system that is just as discriminatory. Perhaps, to minimize South African paranoia, this practice could be extended to include all particiants who wish to be considered members of an international community of scientists.

To be effective, this action need not be particularly radical. Even so, there might well be repercussions for South African researchers who signed such a declaration, in that most funding for research stems directly from the government. We feel, however, that this is a sacrifice that people should be allowed to make; for, if conference participants after signing such a document were refused permission to attend (by having their passports confiscated, as has happened in the past), or were deprived of the financial support that should reasonably be theirs, the world would be alerted to a clear case of academic persecution.

This would contribute to the already strong polarization among academics in this country. Scientists would be forced to decide whether to remain part of the international academic community, or to support the isolationist South African government. Many people are riding on the shirttails of our liberal institutions, without actively supporting an end to apartheid. We feel that the time has long passed for ambivalence with regard to the issues confronting this country. It is important for the academics who have a commitment to the future of a non-racist, democratic South Africa to unite against apartheid policies.

Department of Zoology,

Judith Masters Neil CaIthiness

Bernard Price Institute for

Palaeontological Research,

University of the Witwatersrand,

1 Jan Smuts Avenue,

Johannesburg 2001, South Africa

\section{The role of advocacy}

SIR-N. Hetherington's commentary on legal eagle Edwin Hubble (Nature 319, 189; 1986) considers advocacy as an integral part of science, to be recognized and studied. I agree that the subject should be studied.

Scientists are normally concerned with collecting data, and publishing their findings in the literature. The published data provide a basis for other scientists to make independent judgements on the correctness or incorrectness of hypotheses. However, if a scientist "orchestrates" the evidence in such a manner that only selected data are published, the ability of peers in the scientific community to evaluate hypotheses may be seriously impeded. If "advocacy" in science means the selective presentation of available data for publication in the literature, I believe it is problematic.

Advocacy is an integral part of law. Attorneys are normally concerned with achieving a favourable result for the client. Advocating a theory or position that may achieve a favourable result for a client is not necessarily consistent with full revelation of the available facts.

Science involves a search for truth, rather than the achieving of favourable results for clients. Perhaps advocacy should be left to the legal profession, and scientists should concentrate on full, unqualified disclosure of all available data to their peers.

103 Canterbury Drive,

LEO UZYCH

Wallingford, Pennsylvania 19086, USA

\section{More on Sakharov}

SIR-I appreciate all that Zhores Medvedev ${ }^{1}$ has said on the scientific merit of Andrei Sakharov. My letter ${ }^{2}$ exhibits only my own understanding that a head of a scientific school is a person who promotes current research as leader of a group of scientists. The well-known hard circumstances of the self-sacrificing life of $\mathrm{Dr}$ Sakharov deprive him, unfortunately for all of us, from being a head of a school in this sense.

My personal vision influences also my appraisal of the achievements of $\mathrm{Dr}$ Sakharov. I believe that in the rank of highest human intellectual achievements and accumulation of information of vital importance, applied science is subordinate to fundamental science. In alliance with humanism and religion, fundamental science is the major contributor to the progress of humanity and also to our primary hope for surviving in the irrevocable crises of human environment and human society. The phenomenon of gravity, in its relation to space-time and causality, has been the greatest challenge to the human intelligence and ability to comprehend nature. The potentialities of an advanced theory of gravity can be enormous. So, in my personal view, no further words are required to expound the standing of Sakharov if the question "Who unravelled the mystery of gravity?" is answered: Newton, Einstein and Sakharov.

I welcome the Medvedev letter that gives an additional opportunity to draw the attention of the Soviet authorities to the urgent obligation to Sakharov across all political barriers.

Washington University, St Louis, Missouri 63130, USA

Medvedev, A. Zh. Nature 319, 93 (1986) . Gliner, E.B. Nature 318, 513 (1985)

\section{Comet RNA shock}

SIR-In view of recent correspondence on deciphering primitive evolution from bumps on ribosomes, and in the light (or blackness?) of Professor Hoyle's theory that life originates in comets, is it significant that the nucleus of Halley's comet looks exactly like the small subunit of a ribosome?

JOHN H. ROGERS

MRC Laboratory of Molecular Biology,

Hills Road,

Cambridge CB2 2QH, UK

\section{Correction}

THE British Library Lending Division is at Boston Spa, West Yorkshire. In a letter about PhD theses from Sheila M. Mould (Nature 319, 616; 1986), it was said to be at Leamington Spa; this was a typographical error 